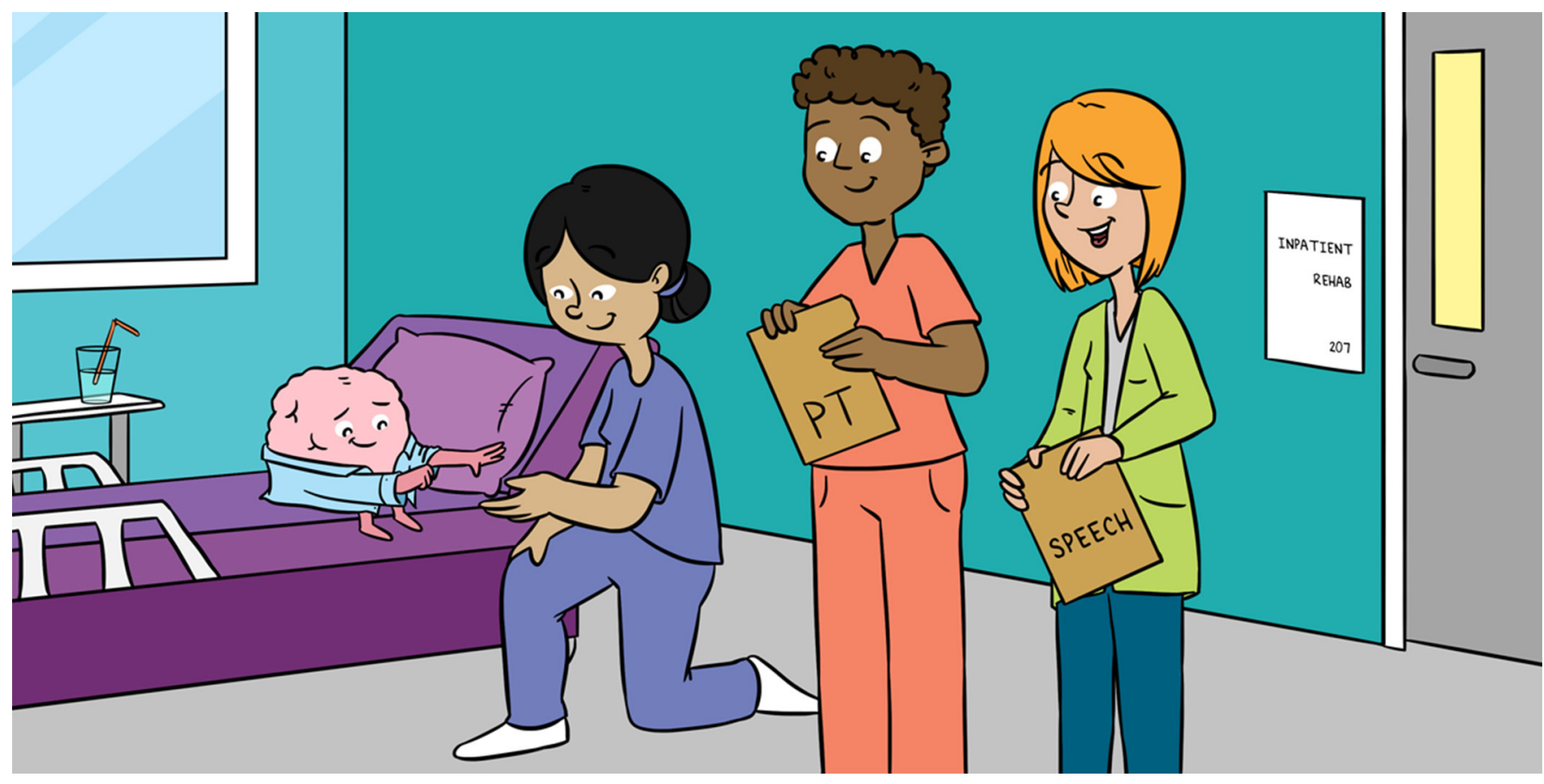

\title{
WHAT IS RECOVERY LIKE AFTER TRAUMATIC BRAIN INJURY?
}

\section{Emily L. Morrow* and Melissa C. Duff}

Department of Hearing \& Speech Sciences, Vanderbilt University Medical Center, Nashville, TN, United States

YOUNG REVIEWER:

SOPHIA

AGE: 9
In the movies, many characters heal very quickly after getting hurt. Some, like Wolverine or Rapunzel, even have special healing powers. However, when a person gets hurt in real life, it may take a lot of patience and hard work to get better. People who are recovering from an injury may also need support from the community and care from healthcare and educational professionals. In particular, it takes time and hard work to recover after a traumatic brain injury (TBI). People with TBI work with a special group of professionals, called a rehabilitation team, to get better. In this article, we will learn about a boy named Dante, who had a TBI after falling off his bicycle. We will learn what happened in Dante's brain after he got hurt and how his rehabilitation team helped him after his TBI. We will finish up by talking about how you can help people with TBI in your community.

Even though you cannot see your brain, it is the most complicated part of your body. Your brain controls how you move, think, and experience the world. It controls things that you do intentionally, like the words 
TRAUMATIC BRAIN INJURY (TBI)

Damage to the brain that is caused by an external force. TBI may result in changes in many different brain functions, including moving, thinking, or communicating.

\section{DIFFUSE AXONAL}

\section{INJURY}

Damage to axons (connections between brain cells) that results from TBI and may affect how the brain functions as a whole. you say. Your brain also controls things you do not even notice, like staying balanced when you are sitting in a chair. Considering how important the brain is, it makes sense that a brain injury could be a big deal. A traumatic brain injury (TBI), which is an injury that happens when an external force damages the brain, may change every part of a person's life. Some disabilities after TBI are physical, like when someone has problems with balance and uses a wheelchair. However, many disabilities after TBI are not physical, but have to do with thinking or communication skills. These disabilities may be hard for others to recognize or understand. That is why $\mathrm{TBI}$ is sometimes called an "invisible injury."

\section{WHAT HAPPENS WHEN THE BRAIN GETS HURT?}

TBI happens when an external force damages the brain. Some common causes of TBI are car accidents, falls (like when riding a bike or playing sports), or getting hit on the head. TBI is quite common. More than 2 million Americans (including 800,000 children) seek medical care for a TBI every year [1].

One challenge in helping people with $\mathrm{TBI}$ is the fact that every single $\mathrm{TBI}$ is unique. There are many different types of damage to the brain. TBI may include damage that is focal, which means there is damage in a specific part of the brain. For example, a person may have a bruise in the frontal lobe, which is the front part of the brain. However, TBI is also diffuse, which means that it affects multiple parts of the brain. Your brain contains 60 billion neurons, or nerve cells, that have their own special functions to control. Those nerve cells connect through long fibers called axons. Axons allow different parts of the brain to work together. In diffuse axonal injury, some of the axons connecting different parts of the person's brain are damaged or die. This causes big changes in the connections and functions of the brain. Look at Figure 1 to learn more about how TBI might damage the connections between parts of the brain.

A person's TBI may also change over time. A person may have primary injuries, which happen immediately, such as a bruise in the frontal lobe. However, secondary injuries may happen from minutes to days after the primary injury. Secondary injuries may include brain swelling and bleeding, a lack of oxygen to the brain, or disturbance to electrical activities in the brain.

Because TBI results in damage all over the brain, it causes problems with the brain's many important functions. For example, a person with $\mathrm{TBI}$ may be in a coma because there is a change to the brain's ability to stay alert. After waking up from the coma, the person may notice changes to movement and balance, problems with senses like vision or hearing, headaches, and sensitivity to noise or lights. Some people may have problems with thinking, learning, and communicating. Some 
Figure 1

(A) Your brain's 60 billion nerve cells connect through long fibers called axons. Axons allow signals to travel through the brain so that different parts of the brain can work together. (B) In TBI, depending on the types of force on a person's brain, axons might be stretched, squeezed, or twisted. Afterwards, the axon may not work well or at all, which can impair the connections between brain cells.

\section{REHABILITATION}

A special medical service focused on helping people to regain independence and get back to their lives after an injury or illness.
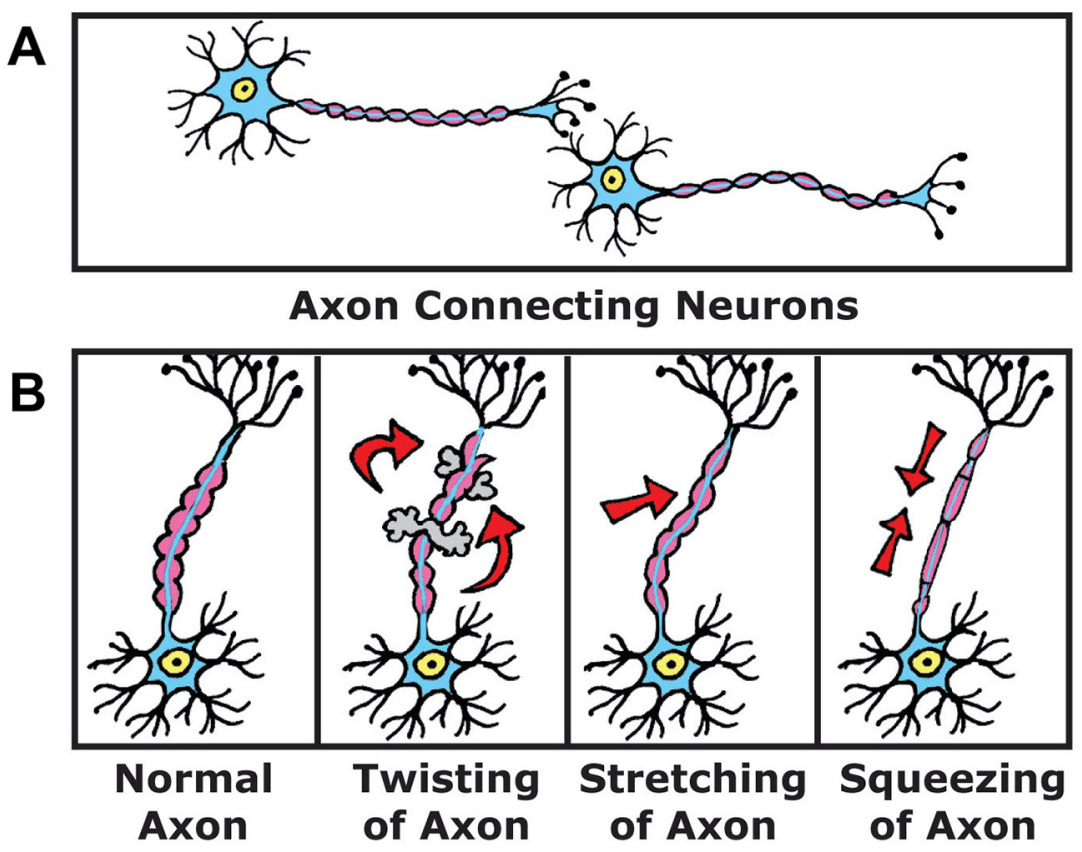

Figure 1

may also notice changes in emotions and behaviors [2]. For example, a person who has problems with communication may have a hard time keeping up with conversation or understanding jokes or teasing. This may be especially challenging at school. It might be difficult to know where to fit in and who is a friend. People with TBI may also get frustrated or angry very quickly. Family, friends, and teachers might not understand that these problems relate to TBI and may not know how to help. When you think about how serious the effects of a TBI may be, it makes sense that there are special teams dedicated to helping people with TBI.

\section{HOW CAN REHABILITATION HELP AFTER TRAUMATIC BRAIN INJURY?}

After a TBI, a person may spend some time in the hospital recovering from severe medical problems. In some cases, the person may need help to breathe or eat. The hospital team will make sure that the person is safe and comfortable enough to leave hospital care so that the next part of the rehabilitation process can begin [3].

Rehabilitation is a medical service focused on helping people to regain independence and to take part in activities of daily life after an injury or illness. After leaving the hospital, some people may go home, and some may go to another facility for ongoing care. If a person is ready to take part in daily therapy, he or she may go to a special facility called inpatient rehabilitation. Inpatient rehabilitation is like a school 
Figure 2

Dante's morning in inpatient rehabilitation (A) First, Dante gets up and gets dressed with his occupational therapist. (B) Next, he has breakfast with the other kids in inpatient rehabilitation. (C) After breakfast, he practices walking with his physical therapist. (D) Finally, Dante needs to get some rest before lunch because his TBI makes him very tired. He wants to be ready for more therapy this afternoon!

\section{OCCUPATIONAL} THERAPIST

A rehabilitation professional who helps people complete the daily activities they want and need to do after an injury or illness

\section{PHYSICAL}

\section{THERAPIST}

A rehabilitation professional focused on helping people who have trouble moving and completing important activities after an injury or illness

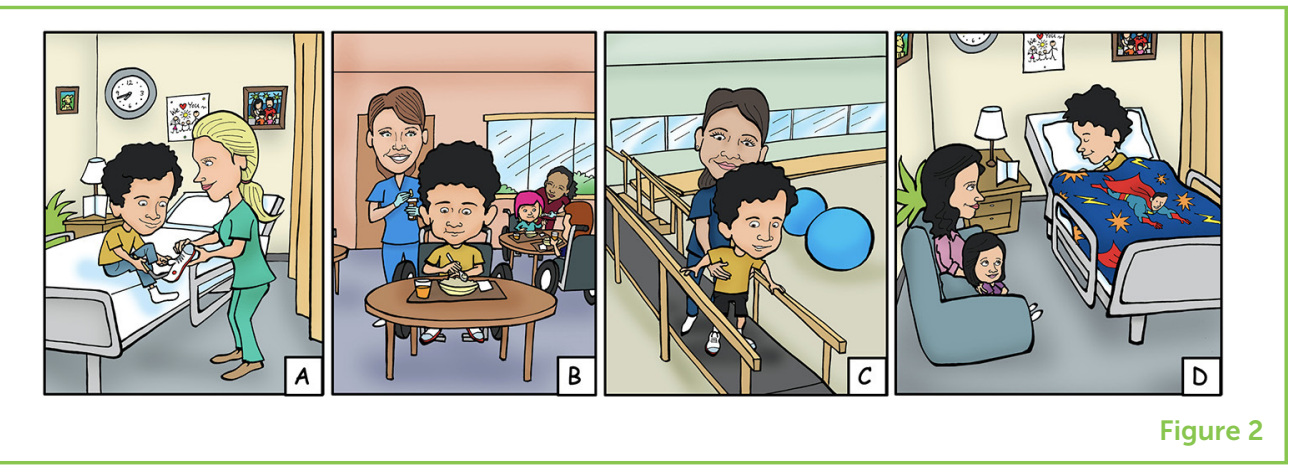

or camp for people recovering after an injury or illness. A child with TBI may go to a special facility that is only for kids [3].

\section{A TYPICAL DAY IN INPATIENT REHABILITATION}

A child who has a TBI will be busy most of the day in inpatient rehabilitation. At first, inpatient rehabilitation may be really hard. People in inpatient rehabilitation go from spending most of the day in a hospital bed to getting up, moving around, and doing lots of activities every day. Some people with TBI may be very tired or frustrated, which makes therapy challenging. We are going to spend a day with Dante, who fell while riding his bike in his neighborhood. Dante was wearing a helmet when he had his accident. Wearing a helmet is important because, in some cases, it can prevent a TBI. In other cases, like Dante's, a helmet can reduce the severity of TBI or even save a person's life. Reviewing Dante's day will help us to learn about what a day in inpatient rehabilitation is like.

Dante wakes up early in the morning to get dressed with his occupational therapist (Figure 2A). Occupational therapists help people do the things they want and need to do after an injury. TBI may change how a person moves his or her hands, fingers, and arms. These changes may make it difficult to button a shirt, tie shoes, or hold a fork. Relearning these skills makes it possible to eat, dress, or complete schoolwork. Occupational therapists may use special tools to make these activities possible, like the shoehorn Dante uses to put on his sneakers.

Next, Dante will eat breakfast (Figure 2B). Today, he is eating in the meal room with other kids. Some of these kids have had TBIs, but others are recovering from other injuries or illnesses. Eating with the other kids allows Dante to practice communication in a social setting. Because Dante is still in a medical facility, his nurse may come by the breakfast room with medications to help with headaches, pain, or seizures.

Next, Dante goes to the gym to work with his physical therapist (Figure 2C). Physical therapists focus on rehabilitation for people who have 
Figure 3

Dante's afternoon in inpatient rehabilitation. (A) After lunch, Dante has speech therapy. (B) Then, he attends rehabilitation school with his friends. (C) While Dante is resting, his parents attend a meeting with his rehabilitation team to learn about his progress and treatment plan. (D) Tonight, Dante will rest well and get ready for another day of hard work tomorrow!
SPEECH-LANGUAGE PATHOLOGIST

A rehabilitation professional who helps people with changes to thinking,

communication, and swallowing after an injury or illness.

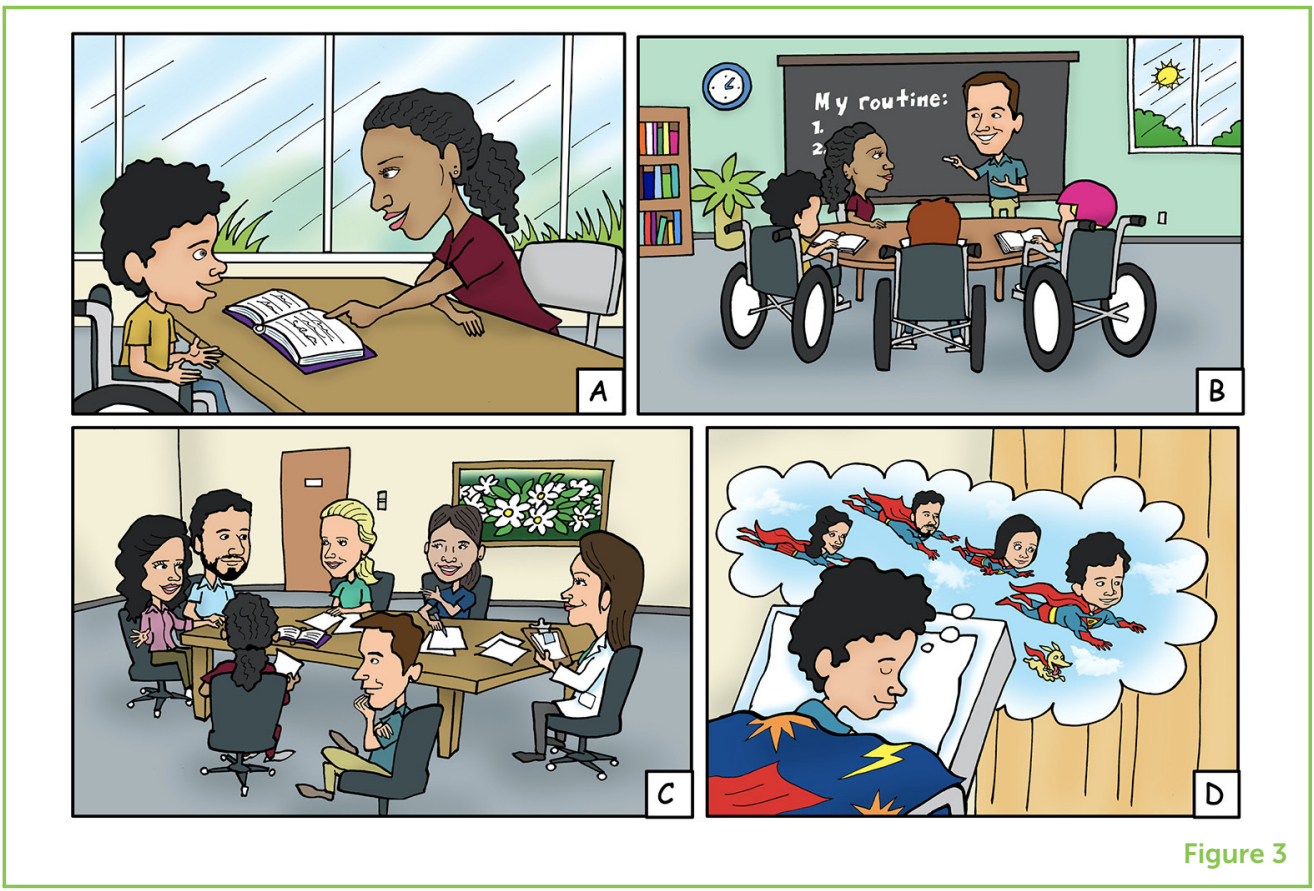

trouble with movement. This may include strength and balance for standing, walking, and changing positions. Dante is walking well, but he has trouble with his balance and gets tired quickly. Today, he and his physical therapist are doing some exercises for standing upright and walking for longer periods of time. After this session, Dante will be tired. He will use his wheelchair for the rest of the day to keep him safe.

Dante has a break before lunch (Figure 2D). After a TBI, people are often very tired after even simple tasks. Dante needs breaks throughout the day!

After lunch, Dante goes to speech therapy (Figure 3A). Speechlanguage pathologists (also called speech therapists) help people with changes to thinking, communication, or swallowing. A speechlanguage pathologist may help a person with TBI to swallow and eat safely. You can see Dante's speech-language pathologist in Figure 2B. She stopped by the breakfast room to make sure that the kids were eating and drinking safely this morning.

Speech-language pathologists also work through changes to speech or language and develop strategies to address communication and thinking problems [4]. In speech therapy today, Dante is working on strategies for his memory. He and his speech-language pathologist have created a memory book. In this book, Dante keeps information about himself, his injury, and his daily activities. Dante uses his book to tell his speech-language pathologist about his day so far. Dante's memory book helps him to track what he learns and to share information with the people he sees throughout the day. 
ACCOMMODATIONS

Changes at school (like more breaks, quiet time, or time to finish assignments) that help a student with a disability (like TBI) to be successful in the classroom
Next, Dante will go to rehabilitation school with some of the other kids (Figure 3B). Rehabilitation school is important because many kids have trouble in school after TBI. Students need to use many of the skills affected by TBI, like thinking, communication, and social skills. Because TBI is an "invisible" injury, some challenges related to TBI might go unrecognized. TBI symptoms may also be diagnosed as something else, like behavior problems.

Everything Dante does in rehabilitation should matter for his daily life $[4,5]$. Going to school is a great way for Dante and his friends to work on their therapy skills in a real-world setting. For example, Dante must pay attention to the teacher and remember his assignments. He must also use social skills to know when to talk and when to listen. During rehabilitation, kids and families may learn about supports, or accommodations, that will help with returning to school. These accommodations are not about changing what a person with TBI learns in school. Instead, they are about making changes to how a student learns so that he or she may get the most from the classroom. Some kids may need more breaks, quiet, or extra time to finish assignments. These types of changes help a student with TBI to stay in his or her regular environment as much as possible.

While Dante rests after school, his parents meet with his rehabilitation team (Figure 3C). In inpatient rehabilitation, all of Dante's physicians, nurses, and therapists work together. This helps everyone to understand Dante's goals and progress [2]. Every person with TBI is different, and every $\mathrm{TBI}$ is different. It is hard to predict how much progress a person will make or how quickly a person will see progress. Many scientists are working on this problem. In the meantime, therapists must customize their plans to each person's strengths, needs, and daily life. That way, the person makes as much progress in therapy as possible.

At this meeting, the entire team updates Dante's parents on his progress in therapy and talks about what he will need when he goes home. This meeting is important because inpatient rehabilitation jump-starts Dante's return to his life after TBI, but it is only a small part of the recovery process $[2,3]$. Dante and his family are the most important members of the rehabilitation team. When Dante goes home after a few weeks in inpatient rehabilitation, he and his family will continue his therapy every day!

\section{WHAT IS MOST IMPORTANT TO KNOW ABOUT TBI IN YOUR COMMUNITY?}

Using Dante's example, we can see that TBI is a serious injury resulting in many changes to brain functions. Although people with TBI may work very hard and see big improvements in therapy, many will 
have changes to thinking, movements, and communication for their whole lives.

People with TBI may have "hidden" disabilities that make it hard to know how and why they could use support. For example, people with TBI may find school and social settings to be difficult, but if others do not understand $\mathrm{TB}$, they may not know why. If you know someone like Dante who has a TBI, make sure to be a good listener, to ask how you can help, and to treat the person with understanding and respect.

Recovery from TBI is a long, challenging process. Returning to life after TBI takes hard work and help from rehabilitation professionals, family, friends, and the entire community. Even though people with TBI do not heal as quickly as characters in movies, we hope that this article has shown that getting back to life after TBI takes super hard work, super community, and super strength!

\section{ACKNOWLEDGMENTS}

The authors thank Tony Bayer for illustrating Figures 1-3.

\section{REFERENCES}

1. Centers for Disease Control and Prevention. TBI: Get the Facts (2019). Available online at: https://www.cdc.gov/traumaticbraininjury/get_the_facts.html

2. DePompei, R., and Blosser, J. L. 2019. Pediatric Traumatic Brain Injury: Proactive Intervention. 3rd Edn. San Diego, CA: Plural Publishing (2019).

3. Im, B., Scherer, M. J., Gaeta, R., and Elias, E. 2010. Traumatic brain injury inpatient rehabilitation. Except Parent (2010) 40:43-6.

4. Ylvisaker, M., Adelson, P. D., Braga, L. W., Burnett, S. M., Glang, A., Feeney, T., et al. 2005. Rehabilitation and ongoing support after pediatric TBI: twenty years of progress. J. Head Trauma Rehabil. 20:95-109. doi: 10.1097/00001199 -200501000-00009

5. Ylvisaker, M. 2003. Context-sensitive cognitive rehabilitation after brain injury: theory and practice. Brain Impair. 4:1-16. doi: 10.1375/brim.4.1.1.27031

SUBMITTED: 04 May 2020; ACCEPTED: 26 November 2020;

PUBLISHED ONLINE: 16 December 2020.

EDITED BY: Robert T. Knight, University of California, Berkeley, United States

CITATION: Morrow EL and Duff MC (2020) What Is Recovery Like After Traumatic Brain Injury? Front. Young Minds 8:559017. doi: 10.3389/frym.2020.559017

CONFLICT OF INTEREST: The authors declare that the research was conducted in the absence of any commercial or financial relationships that could be construed as a potential conflict of interest. 


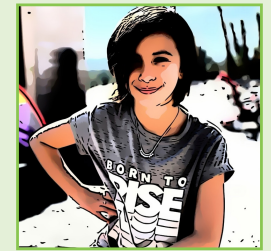

COPYRIGHT () 2020 Morrow and Duff. This is an open-access article distributed under the terms of the Creative Commons Attribution License (CC BY). The use, distribution or reproduction in other forums is permitted, provided the original author(s) and the copyright owner(s) are credited and that the original publication in this journal is cited, in accordance with accepted academic practice. No use, distribution or reproduction is permitted which does not comply with these terms.

\section{YOUNG REVIEWER}

\section{SOPHIA, AGE: 9}

I live in Tucson, Arizona. My favorite sports are swimming and fencing. I play the violin and love to bake. My best friends are my two little brothers. I love to climb trees and indoor rock climbing. My favorite pastime is spending time with my friends. I love to read, and my favorite book series is "Diary of a Wimpy Kid." I am really enjoying being an editor for Frontiers for Young Minds.

\section{AUTHORS}
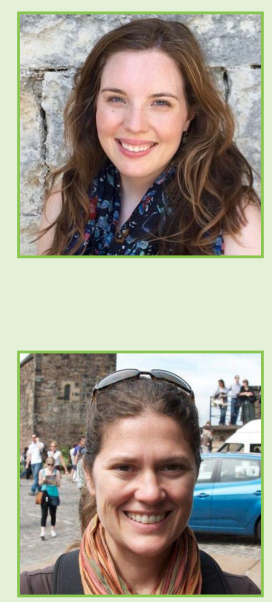

\section{EMILY L. MORROW}

I am a brain injury researcher and speech-language pathologist. I love learning more about the brain and using what we know to help people get back to their lives after brain injury. When I am not in the lab or clinic, I enjoy reading, cooking, traveling, and spending time with family, friends, and my dog! *emily.l.morrowavanderbilt.edu

\section{MELISSA C. DUFF}

I am also a brain injury researcher and speech-language pathologist. I love conducting experiments on how we diagnose and treat people with brain injuries that may improve the rehabilitation process. When I am not in the lab, I like to read, play board games, and travel with my family. 